\title{
PCR amplification of DNA from stained cytological smears
}

\author{
K Gall, D Pavičić, J Pavelić, S Audy-Jurković, K Pavelić
}

\begin{abstract}
DNA from archival Papanicolaou stained smears was successfully amplified using the polymerase chain reaction (PCR) to see if it could be used for retrospective genome studies such as detection of the presence of human papilloma virus (HPV) and changes in p53 gene expression. DNA was isolated and purified by treatment with proteinase $K$, phenol chloroform, and isoamyl alcohol. Segments of the human $\beta$ actin and TGF $\beta 1$ gene were amplified by PCR. Of all stains used in the preparation of Papanicolaou smears, only eosin was detectable as a greenish band in ethidium bromide treated DNA gels under ultraviolet illumination.
\end{abstract}

(f Clin Pathol 1993;46:378-379)

Diagnosis and classification of premalignant and malignant changes in the cervix are mostly based on cytological examination of Papanicolaou stained smears. ${ }^{1}$ Preparation of such smears includes fixation in alcohol and staining with haematoxylin, Orange $G$, and EA polychrome solution. The archival Papanicolaou stained smears could be very useful for the retrospective characterisation of molecular defects leading to malignancy if the DNA from these smears could be successfully amplified using the polymerase chain reaction (PCR). Particularly relevant might be the detection and typing of genital human papilloma virus (HPV) and the characterisation of mutations in the $\mathrm{p} 53$ gene. $^{2}$

Amplification of DNA isolated from archival, unstained, formalin fixed and paraffin wax embedded samples has been successful, ${ }^{34}$ but it was not clear if DNA isolated from stained cytological samples could be amplified with similar success.

Methods
The smears were prepared using a standard
method. ${ }^{1}$ Cells were collected from the poste-
rior fornix of the vagina, cervix, and cervical
canal, spread on the slide, and fixed immedi-
ately in ethanol for 20 minutes. Smears were
stained with Papanicolaou stains (Orange G,
haematoxylin, and EA polychrome solution
consisting of light green sulphonated aryl-
methane dye, eosin and Bismarck brown).

\section{Methods}

Department of Obstetrics and Gynaecology, Medical School, University of Zagreb, Croatia D Pavičić

S Audy-Jurković

Correspondence to: Dr Krešimir Pavelic Accepted for publication 4 November 1992
Unstained smears were used as controls. The smears were mounted in Canada balsam and covered with a glass coverslip. ${ }^{1}$

DNA was isolated from Papanicolaou stained and unstained smears. Two procedures for isolation from the stained smears and one for unstained smears were used. The stained smears were immersed into boiling water for a few seconds to facilitate removal of coverslips. The smears were then washed with xylene for 15 minutes to remove the Canada balsam. The cells were scraped from each slide with a separate clean razor blade and transferred into the Eppendorf microtubes containing $1 \mathrm{ml}$ xylene. Samples were vortexed in xylene for 45 minutes at room temperature. After centrifugation at 12000 $\times g$ for 5 minutes, xylene was carefully removed with a clean Pasteur pipette. The xylene wash was repeated and was followed by two rounds of wash in $1 \mathrm{ml}$ of $100 \%$ ethanol with vortexing at room temperature. The samples were dried in air at room temperature. Then $50 \mu \mathrm{l}$ of digestion buffer ( 50 mM TRIS-HCl, ph 8.5, 1 mM EDTA, $0.5 \%$ Tween 20) containing $400 \mu \mathrm{g} / \mathrm{ml}$ of proteinase $\mathrm{K}$ was added to all samples and incubated overnight at $37^{\circ} \mathrm{C} .^{5}$ The tubes were centrifuged briefly and incubated for $8 \mathrm{~min}$ utes at $95^{\circ} \mathrm{C}$. One set of samples was used for PCR and an identical set was further extracted by three phenol/chloroform and isoamyl alcohol extractions. ${ }^{6}$ The unstained control samples were treated with the proteinase $\mathrm{K}$ /digestion buffer only.

The primer sequences for human $\beta$ actin gene were, respectively, 5'-ATCATGTTTGAGACCTTCAACACCCC-3' and 5'CATCTCTTGCTCGAAGTCCAGGGCGA-3'. These sequences flank a 317 base pair region in the genomic DNA. The guanine, cytosine content of the sequence amplified was $59 \cdot 3 \%$. The primer sequences for human TGF $\beta 1$ were, respectively, 5'-ATCCTGTCCAAGCTGCGGCTCGCCAG-3' and 5'-CGAAAGCCCTCAATTTCCCT CCACG-3'. These sequences flank a 500 base pair region in the genomic DNA and the guanine, cytosine content of the sequence amplified is $60 \cdot 4 \%$.

The 40 amplification cycles comprised 1 minute of denaturation at $95^{\circ} \mathrm{C}, 2$ minutes of annealing at $58^{\circ} \mathrm{C}(\beta$ actin $)$ or at $60^{\circ} \mathrm{C}$ (TGF $\beta 1$ ), and 3 minutes of extension at $72^{\circ} \mathrm{C}$. The PCR was carried out in the total volume 100 $\mu \mathrm{l}$ containing Taq polymerase $(2.5 \mathrm{U})$, dNTPs (2.5 mM each), primers (300 nM), $10 \mu \mathrm{l}$ of $10 \times$ reaction buffer $(100 \mathrm{mM}$ 
TRIS-HCl, ph 8.3, $500 \mathrm{mM} \mathrm{KCl,} 15 \mathrm{mM}$ $\mathrm{MgCl}_{2}, 0.01 \%$ gelatine). PCR products were separated by agarose-gel electrophoresis $(1.2 \%$ agarose stained with $0.5 \mu \mathrm{g} / \mathrm{ml}$ ethidium bromide in TAE buffer).

The corresponding gel was photographed using the orange filter (Agfa-Gevaert), lens aperture $\mathrm{f} / 11$ for 1 minute (figure) and fluorescent filter (IF 550, Olympus), lens aperture $\mathrm{f} / 8$ for 1 minute, respectively (not shown).

\section{Results and discussion}

The figure shows the amplified segment of the $\beta$ actin gene and the TGF $\beta 1$ gene isolated from stained and unstained smears. The $\beta$ actin gene ( 317 base pair) segments amplified from an unstained smear (positive control) and from a stained smear are shown in tracks 2 and 3 , respectively. The band in track 3 appeared somewhat greenish. When the gel was photographed with the fluorescent filter the band in track 3 was intensely green (not

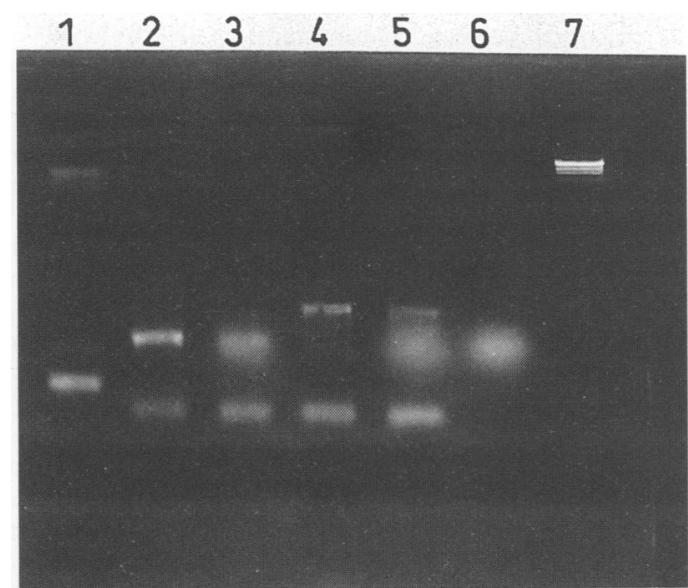

Electrophoresis of PCR amplified 317 base pair fragment of the human $\beta$ actin gene and of the 500 base pair fragment of the human TGF $\beta 1$ gene isolated from unstained cytological smears and smears stained according to the Papanicolaou method (photographed with orange filter).

Line 1 DNA standard, 142 base pair ladder; lines 2 and $4 \beta$ actin and TGF $\beta 1$, respectively, from unstained smears; lines 3 and $5 \beta$ actin and TGF $\beta 1$, respectively, from stained smears; line $6 \mathrm{DNA}$ free $E A$ dye (1 in 100 dilution); line 7 DNA standard, $\lambda /$ Hind III. shown). The photograph taken using an orange filter (figure) differentiated $\beta$ actin from a fluorescent component in the EA dye. Track 4 (figure) shows the amplified part of the 500 base pair TGF $\beta 1$ gene from the unstained smear, and track 5 shows that from the stained smear. Track 6 shows fluorescence originating from the EA stain (diluted 1 in 100) without DNA. The TGF $\beta 1$ fragment amplified from the stained smear migrated free of green fluorescence indicating that there was no interaction between the dye and DNA. This showed that the staining process did not affect DNA protein interactions, but, the greenish fluorescent dye was purified with the DNA in amounts sufficient for easy detection. From the physical characteristics of the dyestuffs used in preparation of Papanicolaou stained smears only eosin emits greenish light under ultraviolet excitation.

No detectable DNA bands were seen with PCR products obtained from stained smears that had not been extracted with phenol/ chlorophorm before PCR.

In conclusion, we isolated and amplified DNA from Papanicolaou stained smears prepared for cytological examination. The procedure did not eliminate all the dye, but the residual amounts did not interfere with the PCR. We believe that the existing archival smears could be used for retroactive studies, for example, to study DNA viruses or gene mutations.

1 Smolka H, Soost HJ. An outline and atlas of gynaecological cytodiagnosis. London: Edward Arnold Limited, 1965:11-12.

2 Scheffner $M$, Werness BA, Huibregtse JM, et al. The E6 oncoprotein encoded by human papilloma virus type-16 and type 18 promotes degradation of p53. Cell and type 18 pron

3 Ben-Ezra J, Johnson DA, Rossi J, et al. Effect of fixation on the amplification of nucleic acids from paraffinembedded material by the polymerase chain reaction. $f$ Histochem Cytochem 1991;39:351-4.

4 Greer CE, Peterson SL, Kiviat NB, et al. PCR amplification from paraffin-embedded tissues. Am $\mathcal{F}$ Clin Pathol 1991;95:117-24.

5 Wright DK, Manos MM. Sample preparations from paraffin-embedded tissues. In: Innis MA, Gelfand DH Sninsky JJ, White TJ eds. PCR protocols: $A$ guide to methods and applications. New York: Academic Press, 1989: 153-8.

6 Sambrook J, Fritsch EF, Maniatis T. Molecular cloning. $A$ laboratory manual. 2nd ed. New York: Cold Spring Harbor Laboratory Press, 1989. 